\title{
Kecemasan Siswa Dalam Menyelesaikan Masalah Modelling Matematika Pada Praktek Kelas Virtual
}

\section{Elsa Nabilah | Khoerul Umam ${ }^{(D)}$ | Ervin Azhar ${ }^{\text {iD }}$ | Sigid Edy Purwanto}

How to cite: Nabilah, E., Umam, K.,Azhar, E.\&\& Purwanto, S., E., 2021. K Kecemasan Siswa Dalam Menyelesaikan Masalah Modelling Matematika Pada Praktek Kelas Virtual. International Journal of Progressive Mathematics Education. 1(1).41-60. https://doi.org/10.22236/ijopme.v1i1.6595

To link to this article : https://doi.org/10.22236/ijopme.v1i1.6595

(C2021. The Author(s). This open access article is distributed under a Creative Commons Attribution (CC BY-SA) 4.0 license.

Sublished Online on March 11, 2021




\title{
Kecemasan Siswa Dalam Menyelesaikan Masalah Modelling Matematika Pada Praktek Kelas VirtuaL
}

\author{
Elsa Nabilah¹, Khoerul Umam® D1, Ervin Azhar1 ${ }^{1 D}$ Sigid Edy Purwanto1
}

Received: 23 Desember 2020 Accepted: 1 Maret 2021 Published Online: 11 Maret 2021

\begin{abstract}
Abstrak.
Latar Belakang. Semakin tinggi jenjang maka tingkat kesulitan matematika akan semakin tinggi juga, dengan demikian meningkatnya kesulitan dalam topik pembelajaran dapat menyebabkan kecemasan terhadap matematika atau dapat mengganggu pemahaman terhadap matematika. Metode Penelitian kuantitatif dengan menggunakan survey dipilih untuk mencapai tujuan penelitian ini. Analisis data penelitian ini menggunakan analisis deskriptif dimana hasil survey interpretasi dengan kajian mendalam dari beberapa penelitian-penelitian terkait. Hasil Penelitian menunjukkan bahwa kecemasan siswa pada kelas virtual tergolong tinggi disebabkan oleh faktor lingkungan yang tidak mendukung untuk proses belajar dan situasi yang membosankan karena selalu dihadapan gadget dalam waktu yang sangat panjang. Kontribusi penelitian ini menambah bagaimana proses pembelajaran secara virtual perlu memperhatikan aspek psikologis siswa dan bagaimana memberikan rasa nyaman dalam belajar walaupun dalam kondisi virtual.
\end{abstract}

Kata Kunci: Kecemasan Matematis, Matematika Modeling, Kelas Virtual

(i) (2)

2021. The Author(s). This open access article is distributed under a Creative Commons Attribution (CC BY-SA) 4.0 license.

Elsa Nabilah

elsa.nabilah.students@uhamka.ac.id

$\varangle$ Khoerul Umam

khoerul.umam@uhamka.ac.id

Ervin Azhar

ervin.azhar.matematika@uhamka.ac.id

Sigid Edy Purwanto

sigid@uhamka.ac.id

${ }_{1}$ Progam Studi Pendidikan Matematika, Fakultas Keguruan dan IImu Pendidikan, Universitas Muhammadiyah Prof. DR. HAMKA, Indonesia 


\section{Latar Belakang}

Pembelajaran matematika di sekolah masih dianggap menyeramkan, sulit dipahami, dan terlalu banyak rumus. Kesulitan mempelajari, memahami, mendeskripsikan materi, dan berkaitan dengan rumus yang banyak merupakan hal-hal yang sering dialami oleh siswa dalam pembelajaran matematika (Abidin, 2020). Hal tersebut menyebabkan sebagian siswa takut dan tidak menyukai pelajaran matematika ditambah lagi suasana pembelajaran matematika yang dianggap membosankan, sehingga menurunkan minat siswa untuk belajar matematika. Asumsi-asumsi tersebut membuat matematika menjadi pelajaran yang dihindari karena menimbulkan kecemasan bagi siswa. Kecemasan matematika (Mathematics Anxiety) adalah kondisi dimana seseorang merasa tidak nyaman dan takut ketika melakukan suatu pekerjaan yang berhubungan dengan matematika. Menurut Wondimu (Wahid, Yusof, \& Razak, 2014) dalam penelitian mereka mengungkapkan terdapat perasaan tidak nyaman seperti, panik, tidak mengerti dan ketidakberdayaan ketika mengerjakan sesuatu yang berhubungan dengan matematika terutama oleh siswa.

Terdapat faktor internal dan faktor eksternal yang menyebabkan timbulnya kecemasan matematika pada siswa. Faktor internal merupakan faktor yang yang disebabkan oleh diri sendiri, yaitu seperti merasa tertekan dengan pelajaran matematika atau mempunyai trauma dengan matematika. Sedangkan faktor eksternal merupakan faktor yang disebabkan oleh berasal lingkungan sekitar seperti, suasana pembelajaran yang terlalu tegang dan cara guru menyampaikan materi yang membuat siswa tidak mengerti. Menurut Wahyudin (Anita, 2014) kecemasan guru terhadap kemampuan matematika mereka sehingga tidak maksimalnya penyampaian materi merupakan salah satu dari faktor yang menyebabkan timbulnya kecemasan matematika siswa di sekolah. Tidak hanya pada siswa, mahasiswa pun merasakan kecemasan terhadap matematika. Kemudian menurut Prima (Wahid et al., 2014) kecemasan matematika di kalangan mahasiswa teknik terjadi dikarenakan subjek yang sulit, selalu gagal dalam matematika, selalu menulis dalam bentuk matematika, merasa cemas jika tidak mengerti dan kehilangan minat pada pelajaran matematika.

Semakin tinggi jenjang maka tingkat kesulitan matematika akan semakin tinggi juga, dengan demikian meningkatnya kesulitan dalam topik pembelajaran dapat menyebabkan kecemasan terhadap matematika atau dapat mengganggu pemahaman terhadap matematika (Yüksel-Şahin, 2008). Menurut Gierl \& Bisanz, Kazelskis, Townsend (Yüksel-Şahin, 2008) bahwa kecemasan matematika dapat dialami sebagian siswa karena mereka menganggap bahwa kinerja dalam matematika adalah ukuran harga diri mereka dan takut kehilangan persepsi baik atau penilaian diri yang baik di mata orang tua dan guru jika nilai matematika mereka rendah, sehingga siswa mengalami kekhawatiran terhadap matematika yang diekspresikan dengan "saya tidak bisa matematika" atau "saya benci matematika". Namun, karena mereka harus berurusan dengan matematika hal ini menyebabkan banyak kesusahan dan kegelisahan.

Adolphus pada tahun 2012 mengutarakan bahwa geometri merupakan materi dalam pembelajaran matematika yang sulit dipahami dan ditakuti siswa hal tersebut dikarenakan masih kurangnya kemampuan pemecahan masalah pada siswa (Safrina, Ikhsan M, \& Ahmad, 2014). Kemudian salah satu materi matematika yang ditakuti oleh siswa adalah aljabar, sulitnya siswa dalam menganalisis soal dan gambaran yang buruk tentang materi aljabar menjadi salah satu alasan materi tersebut ditakuti (Hasibuan, 2015). 
Dalam pembelajaran matematika terdapat modelling matematika (Mathematical Modelling), yaitu suatu pembelajaran matematika yang dimana materi yang disampaikan berkaitan dengan kehidupan nyata. Modelling matematika ialah matematika yang digunakan dalam menyelesaikan masalah non-matematika yang dimana modelling matematika atau pemodelan matematika mengacu pada proses mengubah masalah di dunia nyata menjadi masalah matematika, memecahkan masalah matematika dan menggunakan hasil untuk mengatasi masalah dunia nyata awal (Czocher, Melhuish, \& Kandasamy, 2020). Tujuan dari modelling matematika adalah mempermudah pemahaman siswa terhadap materi matematika karena pembahasan yang diberikan selaras dengan kehidupan nyata. Menurut (Huincahue, Borromeo-Ferri, \& Mena-Lorca, 2018) pengembangan teori pemodelan matematika sebagai kasus paradigmatik yang bertujuan untuk mengembangkan teori dalam interaksi dengan praktik mengajar.

Belakangan ini dunia digemparkan oleh salah satu virus yang menular yaitu Covid-19, yang dimana virus tersebut dalam beberapa bulan penyebarannya sudah ke berbagai negara, salah satu dari negara-negara tersebut adalah Indonesia. Efek dari menyebarnya virus ini terhadap pembelajaran ialah diberlakukannya Pembelajaran Jarak Jauh (PJJ) dengan menggunakan konsep kelas virtual. Kelas virtual adalah dimana pembelajaran yang dilakukan berbasis digital, pada pembelajaran ini memungkinkan siswa dapat belajar di rumah masing-masing. Menurut (Blaine, 2019) pendidikan online jarak jauh dapat diartikan sebagai konteks pendidikan dimana guru dan siswa dipisahkan oleh ruang dan waktu Pada praktek kelas virtual terdapat penyampaian materi oleh guru, diskusi atau interaksi antara guru dengan siswa atau siswa dengan siswa lainnya, pemberian video pembelajaran dan tes untuk mengetahui hasil belajar. Akan tetapi pada kenyataannya konsep kelas virtual ini dapat menyebabkan kecemasan pada siswa dalam beberapa pelajaran salah satunya pada pelajaran matematika. Hal ini terjadi karena pembelajaran menggunakan video tersebut membuat siswa kurang mengerti dan tidak memahami konsep dari materi yang disampaikan dengan baik. Kemampuan pemecahan masalah merupakan salah satu hal yang penting dalam pembelajaran matematika, namun bila siswa tidak dapat memahami konsep dari suatu materi dengan baik maka mereka akan kesulitan dalam hal menyelesaikan masalah. Seperti yang diketahui modelling matematika merupakan salah satu pembelajaran yang berhubungan dengan kehidupan nyata atau sehari-hari yang dimana dapat mempermudah pemahaman siswa.

\section{Kajian Teori}

\subsection{Kecemasan Matematika}

Kecemasan matematika diartikan sebagai perasaan tegang dan cemas yang mengganggu memanipulasi angka dan pemecahan masalah matematika dalam kehidupan nyata dan situasi akademis. Istilah kecemasan matematika (Mathematics Anxiety) merupakan suatu hal yang nyata terjadi pada sebagian orang terutama pada siswa, namun masih diabaikan pula oleh beberapa orang. Menurut penelitian yang dilakukan sebelumnya bahwa sebagian besar anak-anak di sekolah dasar dan sekolah menengah menderita kecemasan matematika (Mathematics Anxiety) yang berhubungan negatif dengan keterampilan berhitung (Passolunghi, Caviola, De Agostini, Perin, \& Mammarella, 2016). Kecemasan matematika merupakan situasi yang terjadi pada sebagian orang ketika menghadapi suatu masalah matematika. Perasaan baik terhadap matematika membawa persepsi 
baik tentang matematika, begitu pula sebaliknya. Menurut Wondimu (Wahid et al., 2014) dalam penelitiannya menjelaskan bahwa kecemasan matematika (Mathematics Anxiety) merupakan perasaan tidak tenang seperti panic, tidak mengerti dan tidak berdaya saat mengerjakan sesuatu yang berhubungan dengan matematika cenderung mempengaruhi kinerja matematika khususnya pada siswa. Pada tahun 1972 Richardson dan Suinn menyatakan bahwa kecemasan matematika ialah perasaan tegang dan cemas yang mengganggu memisalkan angka dan pemecahan masalah matematika dalam kehidupan biasa atau nyata dan situasi akademis, dari pernyataan tersebut tersirat bahwa kecemasan matematika merupakan salah satu penyebab dari beberapa gangguan fungsi matematika (Sherman \& Wither, 2003). Seseorang yang mengalami kecemasan matematika memiliki beberapa sifat negatif dengan matematika, seperti mereka tidak percaya bahwa matematika merupakan ilmu yang berguna, mereka tidak memiliki motivasi dalam melakukan pekerjaan yang berhubungan dengan matematika, dan mereka cenderung akan menghindari kursus matematika dan karir lanjutan yang berhubungan dengan matematika seperti sains dan teknologi, namun tidak hanya orang yang mengalami kecemasan matematika tinggi yang akan menghindari matematika, mereka yng memiliki pretasi matematika yang buruk pun akan melakukan hal yang sama (Maloney, Schaeffer, \& Beilock, 2013).

Menurut Rachman pada 1998 (Taylor \& Fraser, 2013) terdapat empat teori untuk mendefinisikan kecemasan matematika. Dua teori awal ialah prikoanalitik dan biologis dimana menjelaskan bahwa beberapa kecemasan yang dirasakan sisw terjadi di ruang kelas, tetapi hal tersebut tidak menjadi penjadi penyebab utama timbulnya kecemasan matematika pada siswa. Kemudian, dua teori lainnya ialah kognitif dan pembelajaran dimana menjelaskan bahwa kecemasan atau ketakutan yang terkait proses pembelajaran menghasilkan perilaku menghindar atau reaksi yang timbul dari kurangnya pengetahuan terkait suatu peristiwa (teori kognitif) yang terkait secara langsung dengan kecemasan dalam matematika. Kemudian menurut (Bekdemir, 2010) kecemasan matematika adalah perasaan panik, malu, bingung, ingin menghindar, dan takut yang tidak logis yang dapat terlihat secara fisik dimana dapat menghalangi pemecahan masalah dalam pembelajaran dan menghalangi keberhasilan seseorang dalam matematika. Pada penelitian tersebut pula mengungkapkan bahwa kecemasan matematika banyak terjadi pada pra jabatan guru, lalu pengalaman buruk dan pengalaman pada kelas matematika secara negatif dapat mempengaruhi tingkat kecemasan matematika, kemudian secara substansial kecemasan matematika disebabkan oleh perilaku guru yang kurang menyenangkan dan pendekatan pengajaran yang kurang efektif dan efisien, dan persentase siswa yang mengalami pengalaman negatif akan matematika akan meningkat seiring dengan peningkatan jenjang pendidikan dari sekolah dasar ke sekolah menengah pertama kemudian sekolah menengah atas.

Beberapa studi menunjukkan bahwa terdapat sejumlah faktor yang terkait dengan kecemasan matematika. Menurut Uusimaki \& Nason, Woodard (Yüksel-Şahin, 2008) variabel-variabel dari faktor lingkungan seperti tekanan keluarga untuk prestasi yang tinggi, faktor intelektual seperti gaya belajar atau faktor kepribadian seperti tingkat percaya tinggi yang rendah. Dengan kata lain, kecemasan matematika adalah konstruksi multifaset dengan dimensi afektif dan kognitif. Sedangkan menurut Bursal \& Paznokas; Cook; Hadfield \& McNeil; Hopko; Ma \& Xu; Norwood; Reynolds; Thomas \& Furner; Williams; Woodard (Yüksel-Şahin, 2008) kepribadian, konsep diri, kepercayaan diri, gaya belajar, sikap orang tua, harapan tinggi orang tua, sikap negatif terhadap matematika, penghindaran 
matematika, sikap guru, gaya mengajar yang tidak efektif, pengalaman di sekolah yang negatif dan rendahnya prestasi belajar matematika merupakan beberapa diantara konsep dan konstruksi yang berhubungan dengan kecemasan matematika. Pemberian tugas-tugas yang pemecahan masalahnya sengaja dibuat ambigu juga dapat menyebabkan timbulkan kecemasan oleh siswa yang memiliki memori kerja yang rendah namun tidak berpengaruh bagi siswa yang memiliki memori kerja yang tinggi. Kemudian menurut (Harari, Vukovic, \& Bailey, 2013) kecemasan matematika melibatkan gairah fisiologis, kognisi negatif, perilaku menghindar namun tidak dapat lari dari suatu situasi. Meskipun sedikit yang diketahui tentang faktor-faktor yang menyebabkan kecemasan matematika pada siswa, konsepsi di lapangan saat ini bahwa faktor utama yang menyebabkan kecemasan matematika ialah pengalaman negatif di sekolah. Menurut (Vukovic, Kieffer, Bailey, \& Harari, 2013) terdapat dua cara untuk mengkonseptualisasikan kecemasan matematika, yang pertama dengan menganggap kecemasan matematika mencakup dua aspek, yaitu kecemasan numerik dan kecemasan ujian matematika. Kecemasan numerik merupakan kecemasan yang timbul bila seseorang terlibat dalam penggunaan matematika dalam kehidupan sehari-hari atau kehidupan nyata dan dalam kegiatan akademik, sedangkan kecemasan ujian matematika merupakan kecemasan yang berkaitan dengan pengujian atau evaluasi dalam matematika. Konseptualisasi yang kedua ialah menganggap bahwa kecemasan matematika merupakan kecemasan yang sama dengan kecemasan umum, yaitu terdapat komponen kognitif seperti khawatir, dimana seseorang merasakan kekhawatiran ketika melakukan suatu pekerjaan yang berkaitan dengan matematika dan komponen afektif seperti reaksi negatif, dimana terdapat perasaan takut, gugup, dan reaksi fisik yang tidak menyenangkan.

\subsection{Pembelajaran Matematika Pada Kelas Virtual}

Pembelajaran online merupakan pembelajaran yang dikembangkan pada abad 21 ini, hal ini dikarenakan seiring dengan berkembangnya teknologi informasi dan komunikasi. Menurut (Dharmawansa, Nakahira, \& Fukumura, 2013) dalam bidang pendidikan pembelajaran online telah digunakan dibanyak perguruan tinggi dan dalam penelitian, pembelajaran online memungkinkan terciptanya lingkungan belajar yang fokus, hal ini dikarenakan pada pembelajaran online menghemat waktu dan lebih sedikit terdapat ganggungan secara langsung, dari pembelajaran online maka tercipta kelas virtual dimana kelas virtual digunakan sebagai tempat pertemuan antara siswa dengan guru atau instruktur menggunakan komputer atau media digital. Kemudian menurut (Kipnis, Horwitz, \& Stahler, 1998) teknologi pada jaringan komputer telah mengaktifkan ruang kelas virtual dimana bertujuan untuk pembelajaran kolaboratif yang dimana siswa dengan guru berinsteraksi atau berkomunikasi melalu perantara komputer, penmbelajaran kelas virtual juga dianggap lebih kompleks daripada pembelajaran dengan ruang kelas tradisional, dimana materi yang disampaikan dapat dengan mudah diakses dengan sistem jaringan komputer. Pembelajaran berbasis kelas virtual mulai diberlakukan secara merata sejak menyebarnya virus Covid-19 di Indonesia. Pembelajaran kelas virtual adalah pembelajaran online yang menggunakan media pembelajaran seperti video, dalam praktek kelas virtual tidak hanya penyampaian materi dengan video pembelajaran, melainkan terdapat diskusi atau interaksi antara siswa dengan guru, siswa dengan siswa lainnya, dan juga adanya tes hasil belajar. Seiring dengan majunya penggunaan teknologi informasi, pengenalan pemodelan matematika dan aplikasi merupakan fitur umum yang menonjol dari perkembangan praktik pengajaran matematika, terutama yang berkaitan dengan pengajaran tingkat menengah (Huincahue et al., 2018). 
Ruang kelas virtual merupakan lingkungan belajar online yang memungkingkan siswa dengan instruktur atau guru dapat berkomunikasi secara sinkron menggunakan audio, video, obroloan teks, papan tulis interaktifm berbagi aplikai, polling instan dan lain-lain, fitur-fitur tersebut memungkinkan murid dan guru seolah-olah berinteraksi tatap muka di kelas dimana siswa dan guru dapat berbicara satu sama lain, melihat satu sama lain (Parker \& Martin, 2010). Menurut (McLellan, 1998) kelas virtual memungkinkan siswa dapat berpartisipasi dalam kelas kelas berbasis internet di rumah masingmasing, mereka dapat keluar dan masuk halaman web di internet sesuai dengan keinginan mereka. Kelas virtual berbasis internet didasarkan pada kompetensi yang didasari oleh teknologi, seperti komputer, modem, dan perangkat lunak komunikasi, kompetensi teknis dan positif orientasi pada pemecahan masalah memiliki peranan yang penting untuk menerapkan dan berpartisipasi di kelas virtual . Lalu menurut (Morales, Bang, \& Andre, 2013) keterampilan yang dikembangkan siswa dalam kelas virtual tidak hanya mengasimilasi konten akademis, tetapi juga termasuk keterampilan abad 21 seperti bimbingan atau konsultasi dengan teman sejawat, kepemimpinan, berpikir kritis, dan banyak lainnya. Selain itu siswa juga mengembangkan pengarahan diri, motivasi diri, pemberdayaan dan logika pemecahan masalah, ketika siswa mendapatkan masalah dalam pembelajaran, maka maslaahn tersebut akan menjadi tantangan bagi siswa dimana dengan hal tersebut siswa dapat meningkatkan keterampilan dirinya.

Menurut (Hiltz, 1988) kelas virtual merupakan lingkungan belajar mengajar yang dimana pembelajaran tersebut dilakukan dengan perantara komputer sebagai sistem komunikasi, pada pembelajaran kelas virtual siswa berpatisipasi dalam pembelajaran jarak jauh menggunakan komputer pribadi yang dilakukan dari rumah atau dimanapun. Kelas online virtual dirancang dan dikembangkan berdasarkan teori pembelajaran dan teknologi media streaming, untuk membangun kelas virtual bergantung pada teknologi informasi yang mendukung metode dan teori pembelajaran (Yang \& Liu, 2007). Kemudian menurut (Papa, Perugini, \& Spedaletti, 1998) pembelajaran kelas virtual dapat dilakukan dengan memanfaatkan sistem multimedia sebagai akat bantu pendidikan bagi guru, yang dimana berisi fasilitas untuk menangani slide, transparansi, rekaman video, alat pelatihan berbasis komputer dan sebagai alat bantu untuk komukasi interaktif antara guru dengan siswa. Sedangkan Menurut (Taleb, Ahmadi, \& Musavi, 2015) perangkat seluler atau smart phone merupakan salah satu perangkat yang lebih banyak digunakan untuk melakukan pembelajaran kelas virtual, perangkat selular biasanya digunakan untuk mengunduh informasi dalam pembelajaran atau tujuan pembelajaran. Aplikasi pendikan yang terdapat pada perangkat selular dapat memotivasi siswa dan membuat mereka terfokus pada pemecahan masalah, peningkatan daya ingat, bacaan dan kemampuan menulis. Mengubah konsep yang abstrak menjadi konsep yang konkret merupakan suatu hal yang harus dilakukan oleh siswa dalam pembelajaran matematika.

Dalam pembelajaran matematika terdapat kebutuhan yang membuat pemahaman siswa menjadi lebih baik yaitu bagaimana teori psikologis motivasi yang berlaku pada kelas matematika (Kloosterman, 2005). Dalam lingkungan pembelajaran online atau kelas virtual, siswa akan menghadapi masalah pengujian, tugas atau sekedar mempelajari materi dan di dalam proses pembelajaran siswa dapat mengajukan pertanyaan untuk klarifikasi konsep (Kruger-Ross \& Waters, 2013). Pada praktek kelas virtual pembelajaran lebih berpusat pada siswa, menurut (Belcher, 1999) pada lingkungan yang berpusat pada siswa, siswa akan berkomunikasi satu sama lain dan guru berperan sebagai fasilitator daripada pemberi otorisasi dan sebagai penilai kegiatan kelas. Pada 
praktek kelas virtual, visualisasi dalam pembelajaran matematika dapat berupa pemberian video pembelajaran atau penggunaan software-software matematika. Pemberian video pembelajaran matematika pada kelas virtual berisi penyampaian materi matematika yang dijelaskan oleh guru atau instruktur tentang konsep, tujuan, contoh masalah dan penyelesaiannya. Selain dengan pemberian video pembelajaran, pembelajaran matematia pada kelas virtual juga bisa dilakukan dengan diskusi antar siswa, yaitu dimana siswa akan dibagi menjadi beberapa kelompok kemudian setiap kelompok akan diberikan materi secara acak oleh guru lalu mereka akan mendiskusikan materi tersebut dan mempresentasikan atau menjelaskan materi yang telah mereka diskusikan kepada siswa lain. Dalam proses tersebut akan terjadi diskusi dimana ada siswa dari kelompok lain yang menanyakan terkait materi yang dipresentasikan dan siswa yang bertindak sebagai pemapar materi akan menjawabnya, lalu guru akan menjadi pemberi kesimpulan dari materi yang sedang didiskusikan. Selain menggunakan video pembelajaran pada kelas virtual, pembelajaran matematika juga bisa dilakukan dengan menggunakan software matematika. Penggunaan software matematika digunakan untuk mempermudah pelajaran dalam membuat grafik atau kurva, software yang biasa digunakan adalah Geogebra, dengan software ini akan memungkinkan siswa mengetahui bentuk grafik atau kurva dari suatu fungsi.

\subsection{Kecemasan Siswa Pada Materi Modelling Matematika Dalam Kelas Virtual}

Kurikulum matematika pada seluruh pendidikan matematika di dunia memiliki banyak persamaan, salah satunya adalah penggunaan modeiling matematika dalam pembelajaran. Beberapa tahun teraktir, istilah aplikasi atau modelling sering digunakan sebagai ekspresi yang mencakup semua berbagai keterkaitan antara dunia nyata dan matematika (Blum, 1993). Menurut (English \& Watters, 2005) dalam kurikulum matematika kemampuan menafsirkan yang melibatkan proses matematika masih kurang dilibatkan. Menurutnya, proses seperti membangun, menjelaskan, membenarkan, memprediksi, menduga, mewakili, mengkuantifikasi, mengkoordinasikan serta mengatur data merupakan hal penting yang harus dimiliki oleh semua orang. Untuk mengembangkan proses tersebut sesuai dengan pemodelan matematika yang dimana dapat meningkatkan kepercayaan diri dan sikap siswa terhadap matematika serta pemecahan masalah dalam matematika menjadi lebih jelas. Langkah-langkah yang dalam pemodelan matematika yaitu dengan memberikan tujuan dan solusi yang dapat ditafsirkan dengan satu atau lebih dari satu cara. Menurut (Blomhøj \& Kjeldsen, 2006) pemodelan memiliki posisi yang menonjol dalam kurikulum baru matematika, terdapat penekanan yang lebih kuat pada pekerjaan siswa yang dimana dalam pemodelan siswa tidak hanya mengetahui tentang konsep suatu materi, melainkan siswa juga dapat mengetahui berbagai fase dalam proses pemodelan dan siswa akan terlibat pula dalam diskusi serta refleksi kritis tentang model dan pengaplikasiannya. Dalam pemodelan matematika memiliki karakteristik, yaitu membangun, menganalisis, mengkritik, dan dipelajari dengan melakukan tindakan, dalam konteks ini memiliki maksud bahwa pekerjaan yang berorientasi pada masalah pemodelan akan memposisikan siswa sebagai pihak yang menangani tantangan atau masalah tersebut.

Pemodelan matematika merupakan proses menghadapi suatu kondisi yang tidak pasti, mempermasalahkan, membawa penyelidikanm penalaran dan struktur matematika untuk mengubah suatu situasi, pemodelan matematika akan menghasilkan suatu hasil model yang merupakan 
deskripsi dari suatu situasi yang diambil dari materi matematika yang berkaitan dengan pengalaman orang tersebut (Confrey \& Maloney, 2007). Menurut Schwarz \& Kaiser, Srirama (Bala \& Doğanay, 2014) Cheng pada 2001 mengemukakan modelling matematika adalah demonstrasi masalah kehidupan nyata menggunakan istilah matematika dan proses mengubah masalah tersebut ke dalam bahasa matematika. Kegiatan dalam proses ini memudahkan kita untuk melihat masalah kehidupan nyata dengan jelas, untuk mengasosiasikan masalah dengan matematika, untuk mengklarifikasikan dan menggeneralisasikan masalah tersebut dan membuat deduksi. Jadi bisa dikatakan bahwa masalah yang ditemukan dalam pemodelan matematika berasal dari kehidupan sehari-hari siswa maupun kegiatan akademis siswa. Dalam pemodelan matematika terdapat berbagai paragdima, menurut (Haines \& Crouch, n.d.) paradigma tersebut meliputi pendekatan holistic yaitu dimana siswa belajar melalui pengalaman studi yang dimana mereka mungkin akan menemui masalah pemodelan dengan hasil yang sederhana melalui situasi yang sulit, mereka juga menjadi contoh tunggal yang membutuhkan analisis mendalam yang ekstensif pada situasi kompleks. Selanjutnya pemodelan matematika dengan mendefinisikan dan menguji secara rinci proses yang dilalui, pada tahap ini akan berfokus pada proses sehingga siswa tidak berfokus pada pengaplikasian tertentu. Menurut Sokolowski (Bala \& Doğanay, 2014) Blum, Galbraith, Henn, \& Niss mengemukakan tujuan Mathematics Modelling adalah untuk meningkatkan kesenjangan antara penalaran dalam kelas matematika dan penalaran tentang situasi di dunia nyata. Kemudian menurut Ferreira dan Jacobini (Bala \& Doğanay, 2014) Mathematics Modelling memberikan peluang yang sangat baik bagi siswa untuk menggunakan ide-ide mereka di berbagai bidang dan untuk membangun koneksi logis; mengembangkan informasi matematika yang diperlukan dan keterampilan untuk implementasi dengan masalah kehidupan nyata.

Penerapan pemodelan matematika dalam konteks dunia nyata berfungsi sebagai ilustrasi konsep matematika, pemodelan masalah sebagai contoh kontekstual berbasis realitas yang perannya semakin penting. Kompetensi pemodelan berbeda dengan kemampuan pemodelan, tidak hanya kemampuan tetapi juga kemauan untuk menyelesaikan masalah dengan aspek matematika yang diambil dari kehidupan nyata (Kaiser \& Schwarz, 2006). Kemudian menurut (Czocher et al., 2020) pengalaman pemodelan matematika atau modelling matematika memberikan solusi potensial untuk relevansi paradoks karena dalam pemodelan matematika siswa menggunakan pengetahuan matematika mereka untuk memecahkan masalah dunia nyata yang otentik. Hal itu menunjukkan bahwa Mathematical Modelling mampu meningkatkan kemampuan Mathematical Modelling siswa.

Namun, walaupun dikatakan bahwa modelling matematika dapat membantu meningkat pemahaman siswa, tidak berarti modelling matematika tidak menimbulkan kecemasan bagi siswa. Hal ini dapat terjadi dikarenakan pembelajaran dilakukan dalam kelas virtual yang dimana proses pembelajaran yang dilakukan berbeda dari biasanya yang memungkinkan dalam penyampaiannya membuat siswa kurang mengerti. Pembelajaran matematika pada materi modelling matematika dapat menyebabkan kecemasan kepada siswa, hal ini dikarenakan modelling matematika merupakan pembelajaran yang dimana siswa menyelesaikan masalah kehidupan sehari-hari dalam penyelesaian matematika dengan melakukan analisis untuk penyelesaiannya. Dalam tahap menganalisis penyelesaian dari masalah yang diberikan akan menimbulkan kecemasan karena siswa dituntut melakukan penalaran dan berpikir kritis yang dimana sebagian siswa tidak menyukai hal-hal yang mengharuskan mereka melakukan penalaran karena hal tersebut dianggap menyulitkan. Siswa yang 
memiliki kecemasan dalam modelling matematika dapat diketahui secara umum dengan melihat hasil tes matematika tentang modelling matematika, biasanya siswa yang mengalami kecemasan pada suatu materi akan mendapat nilai tes yang rendah, hal ini dikarenakan kurangnya minat siswa untuk mempelajari materi tersebut karena memiliki rasa takut atau trauma. Kecemasan matematika yang dialami oleh siswa dapat diatasi dengan membuat suasana belajar yang menyenangkan dan memberikan contoh masalah matematika dengan situasi yang dialami siswa, sehingga siswa dapat mudah memahami materi yang dijelaskan. Oleh karena itu, menurut (Namkung, Peng, \& Lin, 2019) perlu dilakukan penelitian terkait dengan hubungan kecemasan matematika dengan kinerja matematika. Jika prestasi matematika yang buruk dapar menyebabkan kecemasan matematika, maka upaya intervensi harus dikhususkan untuk meningkatkan keterampilan matematika, namun jika kecemasan matematika menyebabkan kinerja matematika yang buruk, maka upaya intervensi harus difokuskan pada pengurangan kecemasan matematika dan dengan demikian dapat meningkatkan kinerja matematika.

\section{Metode Penelitian}

Dalam penelitian ini menggunakan metode survey dengan pendekatan kuantitaif. Penggunaan metode survey kuantitatif pada penelitian ini dikarenakan peneliti menentukan apa yang ingin diteliti dengan melakukan survey pada sampel dengan memberikan kuesioner yang berisi pernyataan tentang kecemasan siswa sekolah menengah pertama dalam menyelesaikan permasalahan modelling matematika melalui google form. Tujuan utama penelitian ini adalah untuk mengetahui bagaimana kecemasan siswa sekolah menengah pertama dalam menyelesaikan masalah modelling matematika pada praktek kelas virtual dan mengetahui apakah faktor yang mendominasi kecemasan siswa sekolah menengah pertama dalam menyelesaikan masalah modelling matematika pada praktek kelas virtual.

\subsection{Partisipan}

Studi ini dilakukan di Sekolah Menengah Pertama (SMP) atau sederajat di daerah Jakarta, Bogor, Depok, Tangerang, dan Bekasi. Partisipan dalam penelitian ini adalah 200 siswa kelas VII SMP di Jakarta, Bogor, Depok, Tangerang, dan Bekasi yang melakukan pembelajaran daring atau online.

Partisipan dalam penelitian ini dikategorikan menjadi lima aspek, yaitu wilayah, durasi belajar, media yang digunakan ketika pembelajaran daring, platform pembelajaran daring, dan kegiatan yang dilakukan selama masa pandemi. Dalam mengisi survey, pertisipan diminta mengisi beberapa pertanyaan mengenai kecemasan siswa dalam menyelesaikan masalah modelling matematika yang berdasarkan tiga faktor, yaitu faktor emosi, lingkungan dan penilaian.

Tabel 1. Demografi Partisipan

\begin{tabular}{|c|c|c|c|}
\hline \multicolumn{2}{|l|}{ Demografi } & Label & $\mathbf{N}$ \\
\hline Jenis Kelamin & Laki-laki & & 73 \\
\hline & Perempuan & & 127 \\
\hline
\end{tabular}




\begin{tabular}{llc}
\hline Wilayah & Jakarta & 168 \\
& Bekasi & 8 \\
& Tangerang & 8 \\
& Depok & 10 \\
& Bogor & 6 \\
\hline Durasi Belajar & Kurang dari 5 jam & 171 \\
& $10-15$ jam & 24 \\
& Leboh dari 15 jam & 5 \\
\hline Media Pembelajaran & Handphone & 180 \\
& Laptop & 79 \\
& Tablet & 5 \\
& Semuanya & 11 \\
\hline Platform Pembelajaran & Google Classroom & 186 \\
& Whatsapp & 155 \\
& Schoology & 0 \\
& Website dari sekolah & 29 \\
& Website di luar sekolah & 13 \\
& E-mail & 24 \\
& Zoom & 48 \\
\hline Kegiatan yang dilakukan & Bermain & 68 \\
selama masa pandemi & Belajar & 144 \\
& Main Game & 60 \\
& Nonton TV/Youtube & 106 \\
& Media Sosial & 106 \\
\hline & & \\
& & 13 \\
\hline
\end{tabular}

\subsection{Instrumen}

Dalam melakukan suatu penelitian peneliti memerlukan instrumen penelitian, yang dimana instrumen penelitian merupakan alat atau media yang digunakan untuk mendapatkan informasi dari masalah yang akan diteliti. Intrumen penelitian akan diberikan kepada target penelitian atau sampel melalui google form, sampel penelitian pada penelitian ini ialah siswa kelas VII SMP di daerah jabodetabek. Dalam instrumen tersebut berisi tentang pernyataan tentang kecemasan siswa terhadap modelling matematika. Instrumen yang digunakan dalam penelitian ialah kuesioner. Kuesioner dalam penelitian ini menggunakan kuesioner dari (Wahid et al., 2014) yang dimodifikasi sesuai dengan tujuan penelitian yang akan dilakukan.

Dalam instrumen tersebut menggunakan skala likert yang dimana terdapat 30 pernyataan mengenai kecemasan siswa sekolah menengah pertama dalam menyelesaikan masalah modelling matemtika yang terbagi menjadi tiga faktor, yaitu faktor emosi, lingkungan dan penilaian. Pada faktor emosi dan penilaian terdapat lima kategori tanggapan, antara lain "sangat tidak seperti saya", "tidak seperti saya", "agak seperti saya", "seperti saya", dan "sangat mirip seperti saya". Sedangkan pada faktor lingkungan terdapat lima kategori tanggapan pula, yaitu "tidak pernah", "jarang", "kadangkadang", "sering", dan "sangat sering". 


\subsection{Teknik Pengumpulan Data}

Teknik pengumpulan data dalam penelitian ini ialah dengan menyebarkan angket atau kuesioner tentang kecemasan siswa sekolah menengah pertama sederajat terhadap modelling matematika. Langkah-langkah yang dilakukan untuk mengumpulkan data antara lain :

1. Memodifikasi instrumen agar sesuai dengan tujuan penelitian yang akan dilakukan, dimana instrumen tersebut berasal dari (Wahid et al., 2014).

2. Menentukan sampel penelitian menggunakan purposive sampling, yaitu teknik yang digunakan apabila sampel dalam penelitian tersebut ditentukan oleh peneliti sesuai dengan kriteria yang berkaitan dengan tujuan penelitian (Etikan, Musa, \& Alkassim, 2016).

3. Menyebarkan angket atau kuesioner tersebut melalui google form kepada siswa kelas VII sekolah menengah pertama atau sederajat yang melakukan pembelajaran daring atau online.

\subsection{Data Analisis}

\section{Hasil dan Pembahasan}

\subsection{Kecemasan Kategori Emosi}

Untuk mengetahui kecemasan siswa sekolah menengah pertama dalam menyelesaikan masalah modelling matematika maka digunakan statistik deskriptif kuantitatif. Kuesioner atau survey yang telah dimodifikasi disebarluaskan kepada sampel, yaitu 200 siswa kelas VII sekolah menengah pertama (SMP) di daerah Jakarta, Bogor, Depok, Tangerang, dan Bekasi. Dalam penelitian ini partisipasi bersifat sukarela, dan tidak ada resiko atau manfaat yang terindetifikasi partisipan, hasil dari disebarluaskannya survey atau kuesioner tersebut ialah tercapainya jumlah responden yang ditetapkan oleh peneliti, yaitu sebanyak 200 tanggapan.

\begin{tabular}{|c|c|c|c|}
\hline Pernyataan & Mean & SD & Rank \\
\hline $\begin{array}{l}\text { Saya merasa seperti saya tidak dapat memiliki kendali atas nilai saya } \\
\text { dalam matematika yang berbentuk soal cerita. }\end{array}$ & 2.59 & 1.045 & 1 \\
\hline $\begin{array}{l}\text { Saya merasakan jantung saya berdegup ketika melakukan atau berpikir } \\
\text { tentang matematika yang berbentuk soal cerita. }\end{array}$ & 2.48 & 1.298 & 3 \\
\hline $\begin{array}{l}\text { Saya merasa kesal ketika melakukan atau berpikir tentang matematika } \\
\text { yang berbentuk soal cerita. }\end{array}$ & 2.58 & 1.260 & 2 \\
\hline $\begin{array}{l}\text { Saya berkeringat atau tangan berkeringat ketika melakukan atau berpikir } \\
\text { tentang matematika yang berbentuk soal cerita. }\end{array}$ & 2.19 & 1.215 & 4 \\
\hline $\begin{array}{l}\text { Saya merasakan kupu-kupu di perut saya ketika melakukan atau berpikir } \\
\text { tentang matematika yang berbentuk soal cerita. }\end{array}$ & 1.72 & 1.078 & 9 \\
\hline
\end{tabular}




\begin{tabular}{|l|c|c|c|}
\hline $\begin{array}{l}\text { Perut saya menjadi sakit secara fisik ketika melakukan atau berpikir } \\
\text { tentang matematika yang berbentuk soal cerita. }\end{array}$ & 1.66 & 1.036 & 10 \\
\hline $\begin{array}{l}\text { Otot-otot saya merasa tegang dan saya merasa kaku ketika melakukan } \\
\text { atau berpikir tentang matematika yang berbentuk soal cerita. }\end{array}$ & 1.99 & 1.161 & 6 \\
\hline $\begin{array}{l}\text { Saya mengalami kesulitan tidur setelah bekerja pada matematika yang } \\
\text { berbentuk soal cerita atau malam sebelum kelas matematika yang } \\
\text { berbentuk soal cerita atau les matematika yang berbentuk soal cerita. }\end{array}$ & 1.80 & 1.113 & 8 \\
\hline $\begin{array}{l}\text { Saya merasa harus buang air kecil lebih sering ketika di kelas matematika } \\
\text { atau mengerjakan tugas matematika yang berbentuk soal cerita atau tes. }\end{array}$ & 1.91 & 1.186 & 7 \\
\hline $\begin{array}{l}\text { Saya mengalami sakit kepala atau kaku leher ketika melakukan atau } \\
\text { berpikir tentang matematika yang berbentuk soal cerita. }\end{array}$ & 2.19 & 1.300 & 5 \\
\hline
\end{tabular}

Tabel 2 memberikan ringkasan kuesioner siswa. Secara umum, siswa setuju bahwa mereka merasa tidak memiliki kendali atas nilai mereka dalam matematika yang berbentuk soal cerita $(M=$ 2.59, SD = 1.045). Hasil ini sesuai dengan pendapat ( $R$ attan, Good, \& Dweck, 2012) bahwa respon siswa yang menunjukkan kinerja yang rendah dari perspektif instruktur akan menyimpulkan mereka memiliki kemampuan yang rendah. Siswa yang merasa tidak memiliki kendali atas nilai matematika mereka, secara tersirat menunjukkan bahwa mereka memiliki kemampuan matematika yang rendah. Faktor lain yang membuat siswa tidak memiliki kendali atas nilai matematika mereka adalah rendahnya motivasi belajar, pernyataan ini sejalan dengan pendapat Tapia (Zakaria \& Nordin, 2008) bahwa siswa yang memiliki tingkat kecemasan yang tinggi maka memiliki motivasi belajar yang rendah dan sebaliknya. Siswa yang memiliki kecemasan yang tinggi dan motivasi belajar yang rendah salah satunya tidak dapat menguasai dengan baik materi matematika yang berbentuk soal cerita atau modelling matematika, dikarenakan dalam materi ini siswa dituntut untuk berpikir kritis dan melakukan penalaran kepada permasalahan yang tersedia untuk dijadikan penyelesaian matematika.

Ketika siswa tidak dapat memahami suatu materi secara psikis membuat siswa merasa kesal, sesuai dengan pernyataan "Saya merasa kesal ketika melakukan atau berpikir tentang matematika yang berbentuk soal cerita." ( $M=2.58, S D=1.260)$, sejalan dengan pernyataan (Gage, 2012) bahwa matematika merupakan pelajaran yang memiliki banyak subjek verbal yang dapat membuat siswa bingung dimana hal tersebut dapat menimbulkan reaksi emosi yang negatif, reaksi ini tidak terlihat secara jelas namun dapat mempengaruhi pengelolaan informasi pada pembelajaran selanjutnya. Siswa mengalami gangguan psikis saat berhadapan dengan matematika, maka hal tersebut dapat menyebabkan timbulnya reaksi negatif pada fisik pula, seperti pernyataan "Saya merasakan jantung saya berdegup ketika melakukan atau berpikir tentang matematika yang berbentuk soal cerita." ( $\mathrm{M}=$ $2.48, S D=1.298$ ) dan "Saya berkeringat atau tangan berkeringat ketika melakukan atau berpikir tentang matematika yang berbentuk soal cerita." $(M=2.19$, $S D=1.215)$.. 


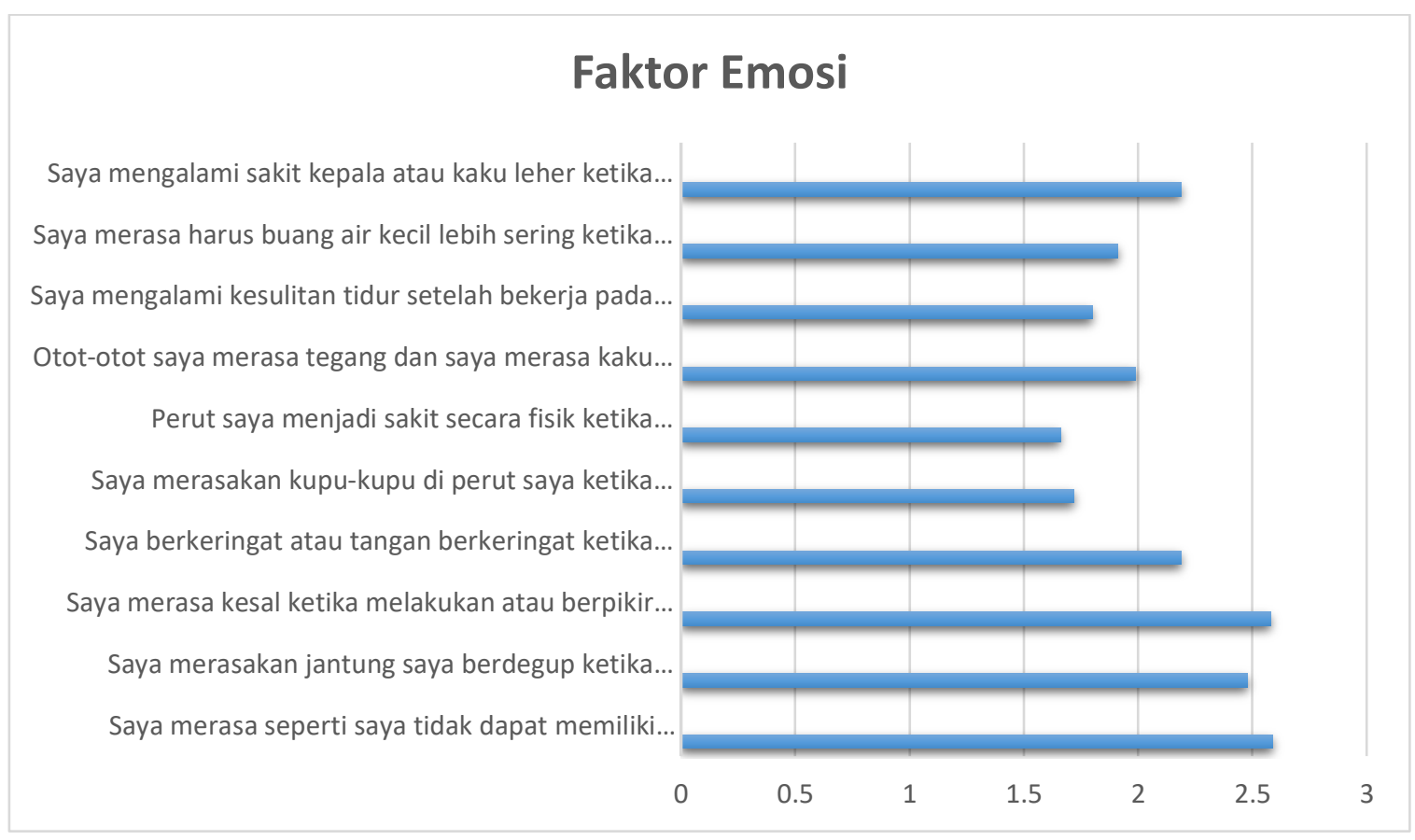

Pernyataan kecemasan rata-rata yang paling dominan pada siswa pada faktor emosi adalah "Saya merasa seperti saya tidak dapat memiliki kendali atas nilai saya dalam matematika yang berbentuk soal cerita." dengan nilai $\mathrm{M}=2.59, \mathrm{SD}=1.025$. Berdasarkan pernyataan tersebut menunjukkan bahwa siswa memiliki kecemasan yang dikarenakan merasa tidak dapat mengendalikan atau mengontrol nilai matematika mereka yang berbentuk soal cerita, hal tersebut dapat disebabkan oleh rendahnya kemampuan matematika yang membuat mereka merasa tidak dapat memahami dengan baik konsep matematika salah satunya dalam matematika yang berbentuk soal cerita. Sedangkan pernyataan kecemasan rata-rata paling sedikit pada siswa pada faktor emosi adalah "Perut saya menjadi sakit secara fisik ketika melakukan atau berpikir tentang matematika yang berbentuk soal cerita." ( $M=1.66, S D=1.036)$. Berdasarkan pernyataan tersebut menunjukkan bahwa skala siswa yang merasakan sakit secara fisik ketika berpikir dengan matematika sedikit, yang berarti siswa tidak memiliki kecemasan akan pengalaman atau kebiasaan matematika yang terlalu buruk. Hal ini selaras dengan (Larkin \& Jorgensen, 2016), yang dimana siswa yang memiliki emosi atau sikap yang negatif terhadap matematika, maka dapat menyebabkan kebiasaan matematika yang negatif pula.

\subsection{Kategori Penilaian}

\begin{tabular}{|l|c|c|c|}
\hline \multicolumn{1}{|c|}{ Tabel 3. Kategori : Penilaian } & Mean & SD & Rank \\
\hline $\begin{array}{l}\text { Pernyataan } \\
\begin{array}{l}\text { Saya cenderung mengerjakan tes matematika yang berbentuk soal } \\
\text { cerita dengan sangat buruk. }\end{array}\end{array}$ & 2.51 & 1.096 & 9 \\
\hline
\end{tabular}




\begin{tabular}{|l|c|c|c|}
\hline $\begin{array}{l}\text { Saya merasa perlu mempersiapkan lebih banyak untuk tes } \\
\text { matematika yang berbentuk soal cerita daripada untuk mata } \\
\text { pelajaran lainnya. }\end{array}$ & 3.20 & 1.278 & 1 \\
\hline $\begin{array}{l}\text { Tes matematika yang berbentuk soal cerita jauh lebih menegangkan } \\
\text { bagi saya daripada tes lainnya. }\end{array}$ & 2.96 & 1.224 & 4 \\
\hline $\begin{array}{l}\text { Ketika belajar untuk tes matematika yang berbentuk soal cerita, saya } \\
\text { menemukan diri saya menunjukkan perilaku cemas. }\end{array}$ & 2.53 & 1.263 & 8 \\
\hline $\begin{array}{l}\text { Saya merasa bahwa saya memahami konsep matematika yang } \\
\text { berbentuk soal cerita tertentu di kelas tetapi melakukan tes dengan } \\
\text { buruk. }\end{array}$ & 2.49 & 1.279 & 10 \\
\hline $\begin{array}{l}\text { Saya mengalami kesulitan berkonsentrasi selama tes matematika } \\
\text { yang berbentuk soal cerita. }\end{array}$ & 2.87 & 1.265 & 5 \\
\hline $\begin{array}{l}\text { Saya tidak merasa percaya diri ketika mengikuti tes matematika } \\
\text { yang berbentuk soal cerita tidak peduli seberapa banyak saya } \\
\text { belajar. }\end{array}$ & 2.80 & 1.326 & 6 \\
\hline $\begin{array}{l}\text { Saya merasa bahwa saya tidak yakin dengan ide/metode solusi saya } \\
\text { selama tes matematika yang berbentuk soal cerita. }\end{array}$ & 2.65 & 1.242 & 7 \\
\hline $\begin{array}{l}\text { Saya biasanya merasa bahwa tes dalam subjek apa pun adalah } \\
\text { cerminan nilai saya sebagai seseorang. }\end{array}$ & 3.07 & 1.198 & 3 \\
\hline $\begin{array}{l}\text { Selama tes matematika yang berbentuk soal cerita, saya } \\
\text { menemukan diri saya membandingkan kemajuan saya dengan } \\
\text { orang-orang di sekitar saya. }\end{array}$ & 3.11 & 1.230 & 2 \\
\hline
\end{tabular}

Tabel 3 memberikan ringkasan kuesioner siswa. Secara umum, siswa setuju bahwa mereka perlu melakukan lebih banyak persiapan untuk menghadapi tes matematika yang berbentuk soal cerita daripada untuk mata pelajaran lainnya $(M=3.20, S D=1.278)$. Salah satu faktor yang mempengaruhi siswa perlu melakukan banyak persiapan untuk menghadapi tes matematika adalah terdapat kecemasan matematika yang dimana membuat siswa merasa takut akan kegagalan, hal ini sesuai dengan pendapat (Greenwood, 1984) bahwa ketakutan akan kegagalan merupakan komponen penting dari kecemasan matematika, oleh karena itu untuk mengurangi resiko kegagalan dalam ujian matematika diperlukannya penguasaan atas materi tersebut, cara melakukan penguasaan suatu materi ialah dengan meningkatkan penguasan pembelajaran terhadap materi secara efektif dan meningkatkan kepercayaan diri.

Ketika siswa merasa cemas saat mempersiapkan ujian, maka secara psikis mereka akan membandingkan kemampuan atau kemajuan mereka dengan orang di sekitarnya, hal ini sejalan dengan pernyataan "Selama tes matematika yang berbentuk soal cerita, saya menemukan diri saya membandingkan kemajuan saya dengan orang-orang di sekitar saya." $(M=3.11, S D=1.230)$. Ketika membandingkan kemampuan diri dengan orang lain dapat terjadi karena timbulnya rasa takut yang menyebabkan munculnya respon negatif pada matematika yang dimana membuat siswa memiliki persepsi negatif akan dirinya terhadap matematika (Ashcraft, 2002) sehingga siswa membandingkan kemampuan mereka dengan orang lain dan adanya rasa rakut gagal atau mendapatkan nilai ujian 
yang rendah dikarenakan nilai merupakan cerminan diri seseorang, pernyataan ini sesuai dengan "Saya biasanya merasa bahwa tes dalam subjek apa pun adalah cerminan nilai saya sebagai seseorang." ( $M=3.07, S D=1.198)$, yang dimana pernyataan tersebut sesuai dengan (Bennett-Levy et al., 2001) bahwa cerminan diri pada dasarnya merupakan evaluasi pikiran dan tindakan pada diri seseorang , dimana ketika seseorang mendapat nilai tes matematika yang rendah, maka penilaian orang lain akan dirinya akan rendah pula begitu juga sebaliknya, ketika siswa mendapat nilai tes matematika yang tinggi, maka penilaian orang lain akan dirinya akan tinggi pula. Terjadinya hal tersebut merupakan salah satu ciri adanya kecemasan siswa pada matematika terutama saat melakukan tes, keadaan tersebut dapat disebabkan karena siswa memiliki mindset bahwa tes matematika merupakan tes yang lebih menegangkan dari tes lainnya, seperti dalam pernyataan "Tes matematika yang berbentuk soal cerita jauh lebih menegangkan bagi saya daripada tes lainnya" ( $M=$ 2.96, SD = 1.224).

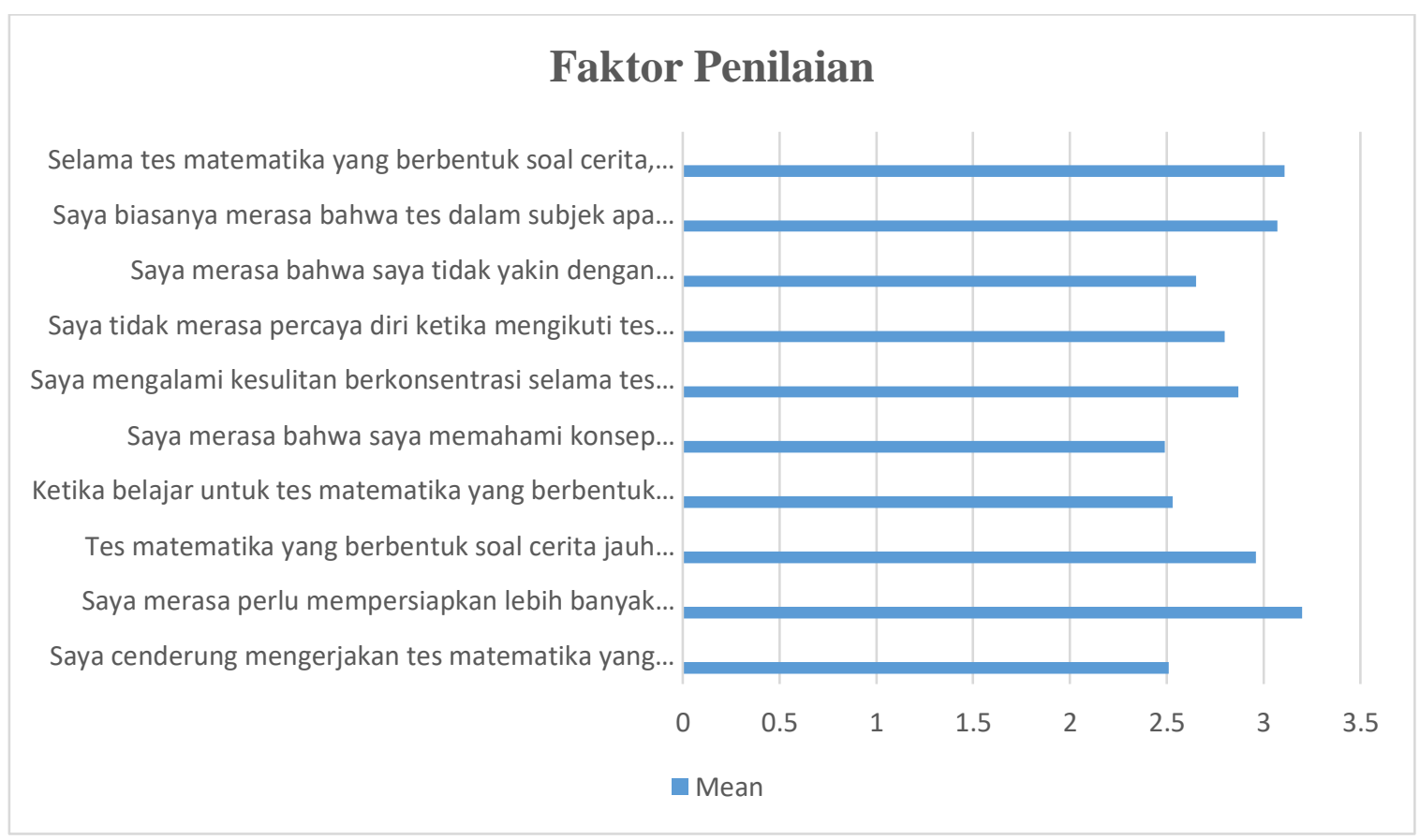

Pernyataan kecemasan rata-rata yang paling dominan pada siswa pada faktor penilaian adalah "Saya merasa perlu mempersiapkan lebih banyak untuk tes matematika yang berbentuk soal cerita daripada untuk mata pelajaran lainnya." dengan nilai $\mathrm{M}=3.20, \mathrm{SD}=1.278$. Berdasarkan pernyataan tersebut menunjukkan bahwa siswa memiliki kecemasan sebelum melakukan tes matematika yang dimana membuat mereka perlu melakukan persiapan yang lebih banyak untuk melakukan tes matematika yang berbentuk soal cerita. Hal tersebut dapat disebabkan karena mereka takut gagal dalam tes atau mereka merasa belum menguasai materi yang berbentuk soal cerita secara baik. Sedangkan pernyataan kecemasan rata-rata paling sedikit pada siswa pada faktor penilaian adalah "Saya merasa bahwa saya memahami konsep matematika yang berbentuk soal cerita tertentu di kelas tetapi melakukan tes dengan buruk." ( $M=2.49, S D=1.279)$. Berdasarkan hasil tersebut menyatakan bahwa siswa tidak mengerjakan tes matematika dengan buruk, hal tersebut dapat dipengaruhi oleh 
metode atau cara pengajaran oleh guru yang efektif, sehingga memudahkan atau membantu siswa dalam memahami materi dan dapat meningkatkan keterampilan pemecahan masalah. Hal tersebut selaras dengan pendapat (Hassan \& Ibrahim, 2013), bahwa kemampuan pemecahan masalah merupakan bagian yang penting dalam pengajaran, jika dilakukan dengan strategi pembelajaran yang efektif dan tepat maka akan membantu siswa dalam mengembangkan kemampuan pemecahan masalah yang berarti akan membantu siswa pula dalam melakukan tes atau ujian.

\subsection{Kategori Lingkungan}

\begin{tabular}{|c|c|c|c|}
\hline Pernyataan & Mean & SD & Rank \\
\hline $\begin{array}{l}\text { Saya merasa bahwa saya tidak akan pernah bisa belajar matematika yang } \\
\text { berbentuk soal cerita tidak peduli seberapa keras saya mencoba. }\end{array}$ & 2.02 & 1.075 & 8 \\
\hline $\begin{array}{l}\text { Saya merasa bahwa orang lain memiliki pikiran yang lebih "matematis" } \\
\text { atau "logis" daripada saya. }\end{array}$ & 2.88 & 1.108 & 1 \\
\hline $\begin{array}{l}\text { Orang tua atau teman-teman saya bercerita tentang perjuangan dan } \\
\text { frustasi mereka dengan matematika yang berbentuk soal cerita. }\end{array}$ & 2.45 & 1.196 & 4 \\
\hline $\begin{array}{l}\text { Saya mengandalkan orang lain untuk membantu saya dengan situasi } \\
\text { matematika yang berbentuk soal cerita sehari-hari. }\end{array}$ & 2.28 & 990 & 5 \\
\hline $\begin{array}{l}\text { Saya merasa bahwa dalam matematika yang berbentuk soal cerita, } \\
\text { jawaban benar atau salah dan ada sedikit ruang untuk apa pun } \\
\text { diantaranya. }\end{array}$ & 2.46 & 1.081 & 3 \\
\hline $\begin{array}{l}\text { Saya memiliki guru matematika yang benar-benar tidak saya sukai karena } \\
\text { satu dan lain alasan. }\end{array}$ & 1.44 & 890 & 9 \\
\hline $\begin{array}{l}\text { Saya merasa khawatir tentang kemampuan matematika yang berbentuk } \\
\text { soal cerita orang lain dan membandingkannya dengan kemampuan saya } \\
\text { sendiri. }\end{array}$ & 2.64 & 1.226 & 2 \\
\hline $\begin{array}{l}\text { Saya merasa bahwa meskipun saya cukup berbakat dalam beberapa hal, } \\
\text { tidak satu pun dari mereka membantu saya dalam matematika yang } \\
\text { berbentuk soal cerita. }\end{array}$ & 2.16 & 1.139 & 6 \\
\hline $\begin{array}{l}\text { Saya pernah dihukum atau dipermalukan di kelas matematika yang } \\
\text { berbentuk soal cerita karena tidak memahami sesuatu. }\end{array}$ & 1.39 & 809 & 10 \\
\hline $\begin{array}{l}\text { Saya merasa seperti saya tidak pernah benar-benar mengerti matematika } \\
\text { yang berbentuk soal cerita dan saya berpura-pura melewatinya.. }\end{array}$ & 2.11 & 1.184 & 7 \\
\hline
\end{tabular}

Tabel 4 memberikan ringkasan kuesioner siswa. Secara umum, siswa setuju bahwa mereka merasa orang lain memiliki pikiran ya ng lebih matematis dan logis daripada mereka ( $M=2.88, S D=$ 1.108), pernyataan tersebut sesuai dengan (Hbbert \& Furner, 1997) dimana siswa yang dengan kemampuan atau pemikiran yang tinggi akan membuat orang di sekitarnya berpikir bahwa mereka mampu secara intelektual dan hal tersebut menjadi ciri dominan dalam diri mereka, sehingga siswa dengan kemampuan atau pemikiran yang rendah akan merasa bahwa pemikiran mereka tidak selogis atau se-matematis orang lain. Siswa yang memiliki pemikiran tersebut akan membuat mereka 
menjadi khawatir dengan kemampuannya, seperti pada pernyataan "Saya merasa khawatir tentang kemampuan matematika yang berbentuk soal cerita orang lain dan membandingkannya dengan kemampuan saya sendiri." ( $\mathrm{M}=2.64, \mathrm{SD}=1.226)$, hal tersebut dapat terjadi karena siswa memiliki rasa takut atau cemas pada matematika, sehingga menimbulkan respon negatif mereka kepada matematika (Ashcraft, 2002).

Hal ini juga dapat terjadi karena siswa merasa kemampuan matematika mereka tidak terlalu baik, namun orang-orang di sekitar mereka memiliki kemampuan matematika yang baik dimana menyebabkan timbulnya rasa tidak percaya diri siswa akan kemampuan dirinya, sehingga siswa membandingkan kemampuan mereka dengan kemampuan orang lain. Hal lain yang membuat siswa merasa cemas pada matematika adalah matematika merupakan pelajaran yang memiliki banyak penyelesaian terutama pada modelling matematika, sehingga kebanyakan siswa bingung apakah penyelesaian matematika yang mereka kerjakan benar atau salah, pernyataan tersebut selaras dengan "Saya merasa bahwa dalam matematika yang berbentuk soal cerita , jawaban benar atau salah dan ada sedikit ruang untuk apa pun diantaranya." ( $M=2.46, S D=1.081)$, ditambah lagi faktor lingkungan sekitar, seperti "Orang tua atau teman-teman saya bercerita tentang perjuangan dan frustasi mereka dengan matematika yang berbentuk soal cerita." ( $M=2.45, S D=1.196)$, dimana sikap takut, cemas atau frustasi pada matematika yang dialami oleh siswa dapat diturunkan kepada anak mereka (Furner \& Duffy, 2002), hal tersebut dapat membuat siswa menjadi semakin cemas dengan matematika dalam bentuk soal cerita..

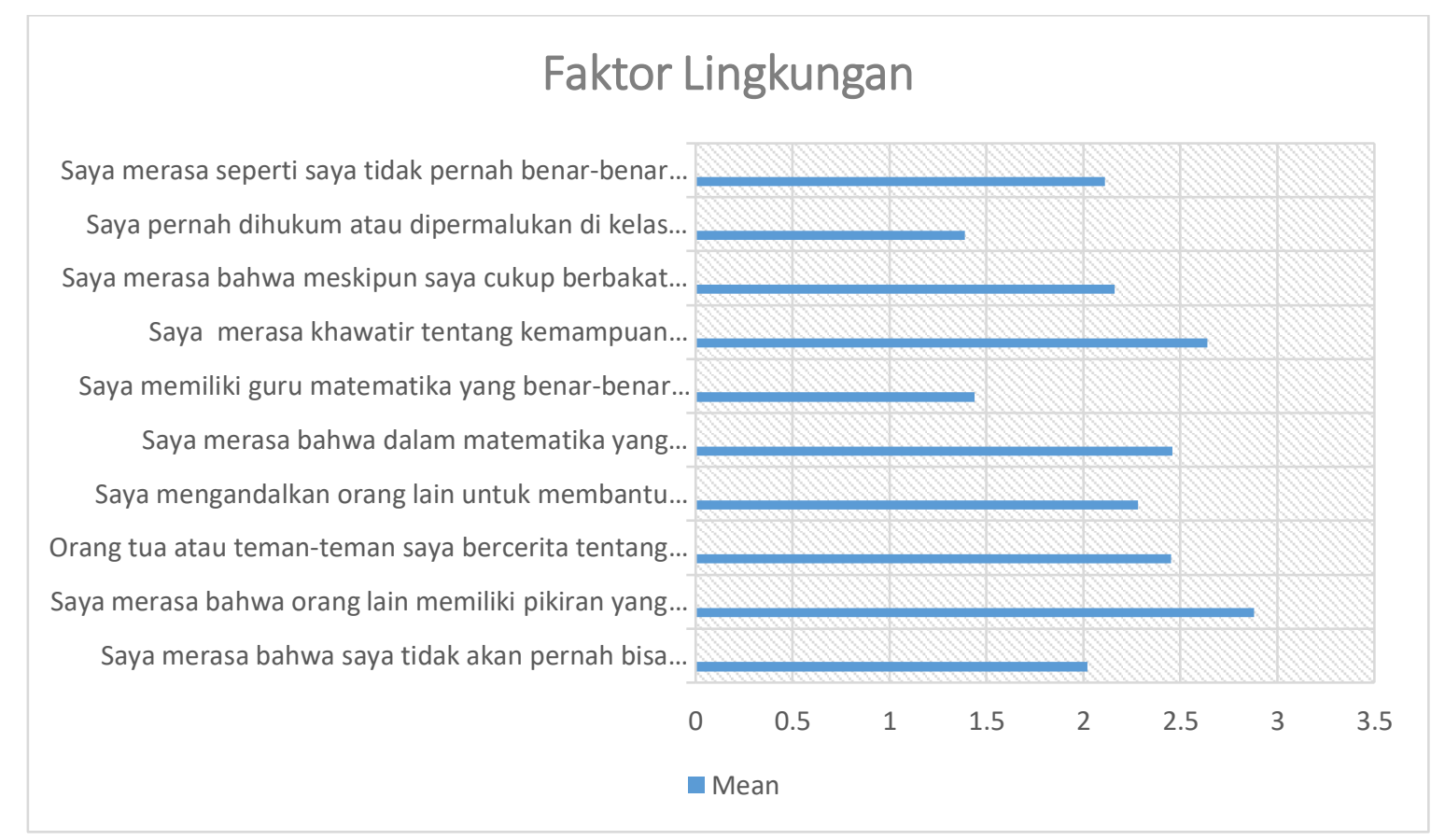

Pernyataan kecemasan rata-rata yang paling dominan pada siswa pada faktor lingkungan adalah "Saya merasa bahwa orang lain memiliki pikiran yang lebih "matematis" atau "logis" daripada saya." dengan nilai $\mathrm{M}=2.88, \mathrm{SD}=1.108$. Berdasarkan pernyataan tersebut menunjukkan bahwa kebanyakan siswa memiliki kecemasan yang dikarenakan merasa orang lain memiliki pola pikir yang 
lebih matemis atau logis darinya, hal tersebut dapat membuat siswa menjadi tidak percaya diri sehingga membuat siswa cemas akan pola pikir yang mereka punya. Sedangkan pernyataan kecemasan rata-rata paling sedikit pada siswa pada faktor lingkungan adalah "Saya pernah dihukum atau dipermalukan di kelas matematika yang berbentuk soal cerita karena tidak memahami sesuatu." $(\mathrm{M}=1.39, \mathrm{SD}=809)$. Berdasarkan pernyataan tersebut menunjukkan bahwa siswa memiliki kecemasan yang rendah dalam hal tidak memahami sesuatu dan pernah dihukum atau dipermalukan di kelas karena hal tersebut, yang dimana berarti guru memperlakukan siswa yang tidak memahami materi dengan baik. Guru tidak hanya memberikan pujian kepada siswa lain yang sudah memahami materi, tetapi juga memberikan dorongan kepada siswa yang tidak memahami materi. Hal tersebut sejalan dengan pendapat (Goegan, Gadsden, Schiefelbein, \& Daniels, 2019), yaitu salah satu perlakuan yang membuat siswa merasa bodoh dan terhina adalah guru memberikan pujian kepada siswa lain sedangkan tidak kepada dirinya.

\section{Kesimpulan}

Kecemasan siswa dalam pembelajaran matematika ternyata tidak hanya pada kesulitan dalam memahami pelajaran, tetapi juga dapat terjadi karena adanya tekanan yang siswa rasakan dari lingkungan sekitar. Terdapat tiga indikator yang menyebabkan kecemasan matematika, diantaranya faktor emosi, faktor penilaian, dan faktor lingkungan. Faktor emosi merupakan faktor yang berasal dari dalam diri atau suatu perasaan yang ditunjukkan kepada keadaan atau seseorang. Kecemasan matematika yang paling banyak disebabkan oleh faktor emosi adalah siswa tidak dapat mengendalikan atau mengontrol nilai matematika mereka, hal tersebut dapat disebabkan oleh kurang baiknya pemahaman konsep matematika oleh siswa yang dimana membuat kurangnya kemampuan matematika siswa, khususnya pada pembelajaran matematika yang berbentuk soal cerita.

Faktor penilaian merupakan salah satu faktor lain yang mempengaruhi kecemasan matematika, faktor penilaian merupakan faktor yang dipengaruhi oleh hasil kerja secara kualitas dan kuantitas yang harus dicapai oleh seseorang. Dalam faktor penilaian, kecemasan matematika yang banyak dialami oleh siswa adalah siswa perlu melakukan lebih banyak persiapan untuk melakukan tes matematika yang berbentuk soal cerita daripada tes lain. Hal tersebut dapat disebabkan karena adanya rasa takut gagal dalam tes, rasa takut gagal tersebut dapat disebabkan karena kurangnya pemahaman konsep matematika yang baik oleh siswa khususnya matematika yang berbentuk soal cerita. Untuk mengurangi rasa takut gagal dalam tes, maka perlu melakukan penguasaan pada materi tersebut.

Faktor lingkungan juga berperan dalam mendukung terciptanya kecemasan. Kecemasan matematis timbul ketika lingkungan belajar yang kurang memadai serta berbagai gangguan belajar yang sulit diprediksi ketika berada di rumah. Bahkan, beberapa siswa merasa kesulitan untuk mengontrol berbagai faktor gangguan yang ditimbulkan oleh lingkungan pada saat belajar. Kecemasan matematika yang paling banyak disebabkan oleh faktor lingkungan adalah siswa merasa orang lain memiliki pemikiran yang lebih matematis atau lebih logis darinya. Hal tersebut membuat siswa menjadi tidak percaya diri dengan pemikiran mereka, sehingga membuat siswa khawatir dengan kemampuannya. 


\section{Penelitian yang Akan Datang}

Pada penelitian yang akan datang perlu dilakukan penelitian kualitatif yaitu penelitian yang menafsirkan maksud dari suatu kejadian dalam interaksi seseorang pada situasi tertentu menurut pandangan peneliti. Penelitian yang hanya menggunakan survey masih kurang reprentatif, untuk itu perlu dilakukan penelitian kualitatif.

Subjek untuk penelitian yang akan datang akan lebih baik jika menggunakan subjek yang berasal dari desa atau daerah terpencil, hal tersebut dilakukan untuk mengetahui hasil penelitian yang lebih spesifik. Pada penelitian ini menggunakan subjek yang luas yaitu siswa sekolah menengah pertama di daerah Jakarta, Bogor, Depok, Tangerang, dan Bekasi atau JABODETABEK, yang dimana subjek diambil dari daerah-daerah maju.

Kecemasan matematika pada penelitian selanjutkan dapat diukur dengan melakukan wawancara dan survey, hal ini dilakukan agar mendapatkan hasil yang lebih konkret. Berbeda dengan penelitian ini yang pengukuran kecemasan matematika hanya dilakukan dengan menggunakan angket atau kuesioner, hal tersebut dilakukan karena tidak memungkinkannya pada penelitian ini menggunakan wawancara dan survey karena sedang tingginya kasus Covid-19 di Indonesia.

\section{Identitas Penulis}

Elsa Nabilah

Email: elsa.students@uhamka.ac.id

ORCID ID: https://orcid.org/0000-0003-2718-7496

Khoerul Umam

Email: khoerul.umam@uhamka.ac.id

ORCID ID: https://orcid.org/0000-0003-3853-7025

Ervin Azhar

Email: ervin.azhar.matematika@uhamka.ac.id

ORCID ID: https://orcid.org/0000-0003-4629-8693

Sigid Edy Purwanto

Email: sigid@uhamka.ac.id

ORCID ID: https://orcid.org/0000-0002-1432-1564

\section{Konflik Kepentingan}

Penulis menyatakan tidak ada konflik kepentingan

\section{Citation information}

Cite this article as: Nabilah, E., Umam, K.,Azhar, E..\& Purwanto, S., E., 2021. K Kecemasan Siswa Dalam Menyelesaikan Masalah Modelling Matematika Pada Praktek Kelas Virtual. International Journal of Progressive Mathematics Education. 1(1).41-60. https://doi.org/10.22236/ijopme.v111.6595. 


\section{Referensi}

Abidin, Z. (2020). Belajar Matematika Asyik dan Menyenangkan. January. https://doi.org/10.31219/osf.io/2hkvm

Anita, I. W. (2014). Pengaruh Kecemasan Matematika (Mathematics Anxiety) Terhadap Kemampuan Koneksi Matematis Siswa Smp. Infinity Journal, 3(1), 125. https://doi.org/10.22460/infinity.v3i1.43

Bala, A. P., \& Doğanay, A. (2014). Improving Primary School Prospective Teachers' Understanding of the Mathematics Modeling Process. Educational Sciences: Theory \& Practice, 14(4), 13751384. https://doi.org/10.12738/estp.2014.4.2042

Bekdemir, M. (2010). The pre-service teachers' mathematics anxiety related to depth of negative experiences in mathematics classroom while they were students. Educational Studies in Mathematics, 75(3), 311328. https://doi.org/10.1007/s10649-010-9260-7

Belcher, D. D. (1999). Authentic interaction in a virtual classroom: Leveling the playing field in a graduate seminar. Computers and Composition, 16(2), 253-267. https://doi.org/10.1016/S87554615(99)00006-7

Blaine, A. M. (2019). Interaction and presence in the virtual classroom: An analysis of the perceptions of students and teachers in online and blended Advanced Placement courses. Computers and Education, 132, 31-43. https://doi.org/10.1016/j.compedu.2019.01.004

Blomhøj, M., \& Kjeldsen, T. H. (2006). Teaching mathematical modelling through project work. ZDMMathematics Education, 38(2), 163-177. https://doi.org/10.1007/bf02655887

Blum, W. (1993). Teaching and learning mathematics in context. Mathematical Modelling in Mathematics Education and Instruction, 1, 3-14.

Confrey, J., \& Maloney, A. (2007). A Theory of Mathematical Modelling in Technological Settings. New ICMI Study Series, 10, 57-68. https://doi.org/10.1007/978-0-387-29822-1_4

Czocher, J. A., Melhuish, K., \& Kandasamy, S. S. (2020). Building mathematics self-efficacy of STEM undergraduates through mathematical modelling. International Journal of Mathematical Education in Science and Technology, 51(6), 807-834. https://doi.org/10.1080/0020739X.2019.1634223

Dharmawansa, A. D., Nakahira, K. T., \& Fukumura, Y. (2013). Detecting eye blinking of a real-world student and introducing to the virtual e-Learning environment. Procedia Computer Science, 22, 717726. https://doi.org/10.1016/i.procs.2013.09.153

English, L. D., \& Watters, J. J. (2005). Mathematical modelling in the early school years. Mathematics Education Research Journal, 16(3), 58-79. https://doi.org/10.1007/BF03217401

Etikan, I., Musa, S. A., \& Alkassim, R. S. (2016). Comparison of Convenience Sampling and Purposive Sampling. American Journal of Theoretical and Applied Statistics, 5(1), 1. https://doi.org/10.11648/j.ajtas.20160501.11

Greenwood, J. (1984). PREVENTING MATH ANXIETY: A PRESCRIPTION.

Haines, C., \& Crouch, R. (2007). Mathematical Modelling and Application : Ability and competence. In Modelling and Applications in Mathematics Education (Blum W., G, pp. 417-424). Elsevier B.V. https://doi.org/10.1007\%2F978-0-387-29822-1_46

Harari, R. R., Vukovic, R. K., \& Bailey, S. P. (2013). Mathematics Anxiety in Young Children: An Exploratory Study. Journal of Experimental Education, 81(4), 538555. https://doi.org/10.1080/00220973.2012.727888

Hasibuan, I. (2015). Hasil Belajar Siswa Pada Materi Bentuk Aljabar Di Kelas Vii Smp Negeri 1 Banda Aceh Tahun Pelajaran 2013/2014. Jurnal Peluang, 4(1), 5-11. 
Hiltz, S. R. (1988). Collaborative learning in a virtual classroom: Highlights of findings. Proceedings of the 1988 ACM Conference on Computer-Supported Cooperative Work, CSCW 1988, 282290. https://doi.org/10.1145/62266.62289

Huincahue, J., Borromeo-Ferri, R., \& Mena-Lorca, J. (2018). Math modeling knowledge from reflection in math teachers initial training. Ensenanza de Las Ciencias, 36(1), 99115. https://doi.org/10.5565/rev/ensciencias. 2277

Jameson, M. M. (2014). Contextual Factors Related to Math Anxiety in Second-Grade Children. Journal of Experimental Education, 82(4), 518-536. https://doi.org/10.1080/00220973.2013.813367

Kaiser, G., \& Schwarz, B. (2006). Mathematical modelling as bridge between school and university. ZDM International Journal on Mathematics Education, 38(2), 196-208. https://doi.org/10.1007/BF02655889

Kipnis, D., Horwitz, S., \& Stahler, S. (1998). The virtual industrial / organizational psychology class : Learning and teaching. 30(2), 205-216.

Kloosterman, P. (2005). Beliefs About Mathematics and Mathematics Learning in the Secondary School: Measurement and Implications for Motivation. Beliefs: A Hidden Variable in Mathematics Education?, 1957, 247-269. https://doi.org/10.1007/0-306-47958-3_15

Kruger-Ross, M. J., \& Waters, R. D. (2013). Predicting online learning success: Applying the situational theory of publics to the virtual classroom. Computers and Education, 61(1), 176184. https://doi.org/10.1016/i.compedu.2012.09.015

Maloney, E. A., Schaeffer, M. W., \& Beilock, S. L. (2013). Mathematics anxiety and stereotype threat: Shared mechanisms, negative consequences and promising interventions. Research in Mathematics Education, 15(2), 115-128. https://doi.org/10.1080/14794802.2013.797744

McLellan, H. (1998). The Internet as a virtual learning community. Journal of Computing in Higher Education, 9(2), 92-112. https://doi.org/10.1007/BF02954768

Morales, T. M., Bang, E. J., \& Andre, T. (2013). A One-year Case Study: Understanding the Rich Potential of Project-based Learning in a Virtual Reality Class for High School Students. Journal of Science Education and Technology, 22(5), 791-806. https://doi.org/10.1007/s10956-012-9431-7

Namkung, J. M., Peng, P., \& Lin, X. (2019). The Relation Between Mathematics Anxiety and Mathematics Performance Among School-Aged Students: A Meta-Analysis. Review of Educational Research, 89(3), 459-496. https://doi.org/10.3102/0034654319843494

Papa, F., Perugini, M., \& Spedaletti, S. (1998). Psychological factors in virtual classroom situations: A pilot study for a model of learning through technological devices. Behaviour and Information Technology, 17(4), 187-194. https://doi.org/10.1080/014492998119391

Parker, M. A., \& Martin, F. (2010). Synchronous virtual classrooms: Student perceptions from an online and blended education course. 2010 International Conference on Technology for Education, T4E 2010, 6(1), 93-100. https://doi.org/10.1109/T4E.2010.5550054

Passolunghi, M. C., Caviola, S., De Agostini, R., Perin, C., \& Mammarella, I. C. (2016). Mathematics anxiety, working memory, and mathematics performance in secondary-school children. Frontiers in Psychology, 7(FEB), 1-8. https://doi.org/10.3389/fpsyg.2016.00042

Rattan, A., Good, C., \& Dweck, C. S. (2012). "It's ok - Not everyone can be good at math": Instructors with an entity theory comfort (and demotivate) students. Journal of Experimental Social Psychology, 48(3), 731-737. https://doi.org/10.1016/j.jesp.2011.12.012

Safrina, K., Ikhsan M, \& Ahmad, A. (2014). Peningkatan Kemampuan Pemecahan Masalah Geometri melalui Pembelajaran Kooperatif Berbasis Teori Van Hiele. Jurnal Didaktik Matematika, 1(1), 920. https://doi.org/10.24815/jdm.v111.1238 
Sherman, B. F., \& Wither, D. P. (2003). Mathematics anxiety and mathematics achievement. Mathematics Education Research Journal, 15(2), 138-150. https://doi.org/10.1007/BF03217375

Taleb, Z., Ahmadi, A., \& Musavi, M. (2015). The Effect of M-learning on Mathematics Learning. Procedia Social and Behavioral Sciences, 171, 83-89. https://doi.org/10.1016/j.sbspro.2015.01.092

Taylor, B. A., \& Fraser, B. J. (2013). Relationships between learning environment and mathematics anxiety. Learning Environments Research, 16(2), 297-313. https://doi.org/10.1007/s10984-013-9134-X

Vukovic, R. K., Kieffer, M. J., Bailey, S. P., \& Harari, R. R. (2013). Mathematics anxiety in young children: Concurrent and longitudinal associations with mathematical performance. Contemporary Educational Psychology, 38(1), 1-10. https://doi.org/10.1016/i.cedpsych.2012.09.001

Wahid, S. N. S., Yusof, Y., \& Razak, M. R. (2014). Math Anxiety among Students in Higher Education Level. Procedia - Social and Behavioral Sciences, 123, 232237. https://doi.org/10.1016/j.sbspro.2014.01.1419

Yang, Z., \& Liu, Q. (2007). Research and development of web-based virtual online classroom. Computers and Education, 48(2), 171-184. https://doi.org/10.1016/i.compedu.2004.12.007

Yüksel-Şahin, F. (2008). Mathematics anxiety among 4th and 5th grade Turkish elementary school students. International Electronic Journal of Mathematics Education, 3(3), 179192. https://www.iejme.com/download/mathematics-anxiety-among-4th-and-5th-grade-turkishelementary-school-students.pdf 